\title{
Durability Properties of Palm Oil Fuel Ash Self Compacting Concrete
}

\author{
Tokunbo Ofuyatan \\ Department of Building, Caleb \\ University Lagos, Nigeria \\ tokunbohofuya07@gmail.com
}

\author{
Festus Olutoge \\ Civil Engineering Department, \\ University of Ibadan, Nigeria \\ folutoge2002@yahoo.com
}

\author{
Adeoye Olowofoyeku \\ Yaba College of Technology, Civil \\ Engineering Department, Nigeria \\ adeolowoo@yahoo.com
}

\begin{abstract}
Self Compacting Concrete (SCC) is a new innovation in technology that can flow readily into place under its own self weight and fill corner areas of reinforcement structures without the need to vibrate and without segregation of its constitute. The problem of durability of concrete structures due to inadequate compaction by skilled workers has become a source of concern globally. The shortage of skilled manpower, noise and vibration of equipment on construction sites has led to the development of self compacting concrete. This paper presents an experimental study on the durability properties of Self Compacting Concrete with partial placement of Palm Oil Fuel Ash (POFA). Twelve POFA self-compacting concretes of various strength grades were designed at varying percentages of $0,5,10,15,20,25$ and $30 \%$. The concrete with no placement of ash served as control. Conplast SP432MS was used as superplasticiser in the mix. The experiments are carried out by adopting a water-powder ratio of 0.36. Workability of the fresh concrete is determined by using tests such as: slump flow, $T_{50}, \mathrm{~V}$-funnel and L-Box tests. The durability of concrete is tested by acid resistance, sulphate attack and saturated water absorption at the age of 14, 28, 56 and 90 days.
\end{abstract}

Keywords-Self-compacting concrete; Palm Oil Fuel Ash; POFA; Water absorption; Acid resistance; Sulphate attack; durability

\section{INTRODUCTION}

The concept of Self Compacting Concrete was first introduced in 1988 [1]. SCC offers many new solutions to the concrete industry, due to its unique rheological properties. During the past 3-4 years the utilization of SCC in Europe has been steadily growing each year. Much research has been made on the rheological properties of SCC and less on the durability of SCC. Zhu et al. [2] studied the transport properties as well as the durability of SCC. They concluded that the chloride migration depended much on the type of solid additives used in the mix. Mörtsell and Rodum [3] compared SCC with normal concrete and found out that for a variety of durability tests, SCC only showed better frost resistance of the skin surface. Makishima et al., [4] studied the frost resistance of SCC. They concluded that SCC has excellent resistance to freezing and thawing, but in order to achieve long-term frost resistance, entrained air is needed. Persson [5] studied the frost resistance of SCC. In his conclusions, he found that internal damage is much less in SCC compared to normal concrete, but scaling is similar between SCC and normal concrete. Contrary to [4] no relationship between the air voids content and frost resistance was documented.

The scope of this research is to study the durability of self compacting concrete, mainly the freeze/thaw resistance and the chloride penetration, and to a lesser extent the interaction between sea-water and concrete (in terms of sulphate attack). Palm Oil Fuel Ash is an industrial by-product, generated from the combustion of coal in the thermal power plants. The increasing scarcity of raw materials and the urgent need to protect the environment against pollution has accentuated the significance of developing new building materials based on industrial waste generated from coal fired thermal power stations creating unmanageable disposal problems. Palm ash, when used as a pozzollan in concrete, improves its strength and durability characteristics. Palm ash is used either as an admixture or as a partial replacement of cement. It can also be used as a partial replacement of fine aggregates, as a total replacement of fine aggregates and as supplementary addition to achieve different properties of concrete [6].

\section{EXPERIMENTAL DETAILS - MATERIALS USED AND MIX COMPOSITION}

\section{A. Cement}

The cement used for the investigation was the Type 1 normal ordinary Portland cement (OPC) that conforms to [7] and was obtained in $50 \mathrm{~kg}$ bags from retailers in Lagos. The sand used in this research is natural river sand, with fines less than $0.125 \mathrm{~mm}$ for the rheology of the SCC. The sand was dried at room temperature for 24 hours to control the water content in the concrete.

\section{B. Coarse Aggregates}

Since the cubes were $150 \times 150 \times 150 \mathrm{~mm}$ in size, the nominal maximum size must not exceed $20 \mathrm{~mm}$ size of coarse aggregate [8]. Crushed aggregate was gotten from Sagamu quarry with nominal size of $10 \mathrm{~mm}$ in accordance to [9]. 


\section{Water}

Portable water supplied which was used for concreting and curing of samples. Water is needed for the hydration of cement and to provide workability during mixing and placing.

\section{Palm Oil Fuel Ash}

The replacement of cement with palm oil fuel ash (POFA) is the key element of this research. POFA was grinded to a suitable fineness which in this research is up to $45 \mu \mathrm{m}$ before it was used in the SCC mix. It was kept airtight and stored in a humid-controlled room to prevent it from being exposed to moisture.

\section{E. Conplast SP432MS}

High performance superplastisizer complying with ASTM C-494 type F [10] was used to produce SCC. Conplast SP432MS is a recent superplastisizer for concrete and mortar. It meets the requirement for set retarding or high range water reducing superplastisizer. The color of Conplast SP432MS is brown.

\section{F. Mix Proportions}

One control and seven SCC mixes with different replacements of Palm ash were prepared and examined to quantify the properties of SCC. Table I and II present the composition of SCC mixtures and sample mix composition. The replacement was carried out at levels of $0 \%, 5 \%, 10 \%$, $15 \%, 20 \%, 25 \%$ and $30 \%$ of cement content. After iterative trial mixes the water/powder mass ratio (w/p) was selected as 0.36 . The total powder content was varied as $450 \mathrm{~kg} / \mathrm{m}^{3}, 500$ $\mathrm{kg} / \mathrm{m}^{3}, 530 \mathrm{~kg} / \mathrm{m}^{3}$ as iterative values and finally fixed at 530 $\mathrm{kg} / \mathrm{m}^{3}$. Some design guidelines have been prepared from the acceptable test methods. Many different test methods have been developed in attempts to characterize the properties of SCC. So far, no single method or combination of methods has achieved universal approval and most of them have their adherents. Similarly, no single method has been found to characterize all the relevant workability aspects. So, each mix design should be tested by more than one test method in order to obtain different workability parameters.

TABLE I. DETAILS OF SAMPLES TO BE USED

\begin{tabular}{|l|l|l|}
\hline Sample & Main Composition & Condition \\
\hline A1 & OPC ONLY & Not Compacted \\
\hline A2 & OPC + POFA & Compacted \\
\hline A3 & OPC + POFA 5\%+SP & Not Compacted \\
\hline A4 & OPC +POFA $10 \%+$ SP & Not Compacted \\
\hline A5 & OPC + POFA $15 \%+$ SP & Not Compacted \\
\hline A6 & OPC +POFA 20\%+SP & Not Compacted \\
\hline A7 & OPC +POFA 25\%+SP & Not Compacted \\
\hline A8 & OPC +POFA 30\%+SP & Not Compacted \\
\hline
\end{tabular}

TABLE II. DETAILS OF SAMPLES MIX COMPOSITION

\begin{tabular}{|c|c|c|c|c|c|c|c|}
\hline Sample & $\begin{array}{c}\text { Cement } \\
\mathbf{( k g )}\end{array}$ & $\begin{array}{c}\text { Sand } \\
\mathbf{( k g )}\end{array}$ & $\begin{array}{c}\text { Coarse } \\
\text { Aggre. } \\
\mathbf{( k g )}\end{array}$ & $\begin{array}{c}\text { Water } \\
\mathbf{( k g )}\end{array}$ & $\begin{array}{c}\text { POFA } \\
\mathbf{( k g )}\end{array}$ & W/b & $\begin{array}{c}\text { Conplast } \\
\text { SP432MS } \\
\mathbf{( \% )}\end{array}$ \\
\hline A1 & 18.97 & 20.54 & 42.78 & 9.76 & - & 0.36 & - \\
\hline A2 & 18.97 & 20.54 & 42.78 & 9.76 & - & 0.36 & - \\
\hline A3 & 21.97 & 20.54 & 42.78 & 9.76 & 3.44 & 0.36 & $2 \%$ \\
\hline A4 & 19.58 & 20.54 & 42.78 & 9.76 & 4.88 & 0.36 & $2 \%$ \\
\hline A5 & 17.01 & 20.54 & 42.78 & 9.76 & 7.32 & 0.36 & $2 \%$ \\
\hline A6 & 15.65 & 20.54 & 42.78 & 9.79 & 9.76 & 0.36 & $2 \%$ \\
\hline A7 & 13.21 & 20.54 & 42.78 & 9.76 & 12.21 & 0.36 & $2 \%$ \\
\hline A8 & 12.54 & 20.54 & 42.78 & 9.76 & 14.78 & 0.36 & $2 \%$ \\
\hline
\end{tabular}

\section{WORKABILITY TEST METHODS}

For determining the self-compactability properties; slump flow, T50 time, V-funnel flow time, L-box blocking ratio, Ubox difference in height tests were performed. In order to reduce the effect of workability loss on the variability of test results, fresh state properties of mixes were determined within a period of 30 minutes after mixing. The order of testing was as below, respectively.

\section{Slump flow test and measurement of $T_{50} \mathrm{~cm}$ time}

2. V-funnel flow test

\section{L-box test}

\section{DURABILITY TEST METHODS}

Durability studies were conducted at 28, 56 and 90 days for various mixes to find out the resistance to acid attack, sulphate attack and saturated water absorption.

\section{A. Acid Resistance}

Acid resistance was tested on $150 \mathrm{~mm}$ size cube specimens at the age of 28 days of curing. The cube specimens were weighed and immersed in water diluted with one percent by weight of sulphuric acid for 14, 28, 56 and 90 days. Then, the specimens were taken out from the acid water and the surfaces of the cubes were cleaned. Then, the weight and the compressive strength of the specimens were measured and the average percentage of loss of weight and compressive strength were calculated.

\section{B. Sulphate Attack}

The sulphate attack testing procedure was conducted by immersing concrete specimens of the size $100 \times 100 \times 100 \mathrm{~mm}$ over the specified initial curing in a water tank. Then, they were cured in 5\% sodium sulphate solution for 28, 56 and 90 days, respectively. This type of testing represents an accelerated testing procedure, which indicates the performance 
of particular concrete mixes to sulphate attack on concrete. The degree of sulphate attack was evaluated by measuring the weight losses of the specimens at 14, 28, 56 and 90 days, respectively.

\section{Saturated Water Absorption}

Saturated water absorption test was conducted on $100 \mathrm{mmx} 100 \mathrm{mmx} 100 \mathrm{~mm}$ cubes at the age of 28 and 90 days. The specimens were weighed before drying in a hot air oven at $1050^{\circ} \mathrm{C}$. The drying process was continued, until the difference in mass between two successive measurements at a 24 hour interval closely agreed. The dried specimens were cooled at room temperature and then immersed in water. The specimens were taken out at regular intervals of time, surface dried and weighed. The difference between the saturated mass and the oven dried mass expressed as a percentage of the oven dried mass gives the saturated water absorption.

\section{RESULTS AND DISCUSSION}

In this study, fresh, hardened properties and durability of self-compacting concrete were investigated by using palm ash waste materials as partial replacement for cement. $2 \%$ superplastisizer was added due to the trial mix that was initially performed. In the present study, properties of self-compacting concrete produced with Oil Palm Ash were investigated based on fresh concrete tests, workability, strength and durability tests.

\section{A. Fresh Properties}

It was observed (Table III) that the slump test for SCC collapsed, while that of A2 was okay due to its compaction. The slump flow $\mathrm{T}_{50}$ of 4, 5, 6 and 7 had good results which were within the acceptable ranges of SCC mixtures. The $T_{50}$ time of 2-3 secs indicate a greater flow-ability, because a lower time taken means a better flow. This indicates that the passing ability, flow-ability and resistance to segregation were within the recommended limits of 650-800 mm and 3-15 secs.

\begin{tabular}{|c|c|c|c|}
\hline Specimen & $\begin{array}{l}\text { Slump flow test 650- } \\
\mathbf{8 0 0 m m}\end{array}$ & $\begin{array}{l}\text { Slump flow } \\
\text { test 2-5 (secs) }\end{array}$ & $\begin{array}{l}\text { Slump } \\
\text { test }\end{array}$ \\
\hline A1 & 350 & - & 30 \\
\hline A2 & 550 & - & 120 \\
\hline A3 & 400 & - & - \\
\hline A4 & 550 & 1 & - \\
\hline A5 & 670 & 2 & - \\
\hline A6 & 720 & 3 & - \\
\hline A7 & 760 & 3 & \\
\hline
\end{tabular}

The L-box test results from the specimen as shown in Table IV indicates a high value of blocking ratio (h1/h2) which was within the standard ratio. The higher the value of blocking ratio the higher the flow-ability of the concrete to compact at its own self weight and a good passing ability without blocking through closely spaced obstacles.

It was observed that with the increase in the palm ash content the weight reduction of the specimens and the compressive strength gets reduced. It was also observed that with the increase in Palm ash content the weight reduction gets decreased when compared with the control mix. It is clear that Palm ash added as cement replacement in concrete enhances the sulphate resistance in concrete. It was alsonoted that with the increase in Palm ash content the saturated water absorption gets decreased when compared with the control mix. Palm ash acts as a filter material which fills the pores and thereby reduces water absorption. Detailed results are shown in Tables IV to VII.

TABLE IV. L-BOX RESULT

\begin{tabular}{|c|c|c|c|}
\hline Specimen & H1(mm) & H2(mm) & H2/H1(mm) \\
\hline A3 & 44 & 36 & 0.82 \\
\hline A4 & 42 & 34 & 0.81 \\
\hline A5 & 38 & 35 & 0.94 \\
\hline A6 & 39 & 37 & 0.95 \\
\hline A7 & 43 & 38 & 0.95 \\
\hline
\end{tabular}

TABLE V. ACID RESISTANCE TEST RESULT

\begin{tabular}{|c|c|c|c|c|c|c|c|c|}
\hline $\begin{array}{c}\text { Mix } \\
\text { proportion }\end{array}$ & \multicolumn{4}{|c|}{$\begin{array}{c}\text { Average reduction in } \\
\text { weight \% }\end{array}$} & \multicolumn{4}{c|}{$\begin{array}{c}\text { Average loss of } \\
\text { compressive strength \% }\end{array}$} \\
\hline 0 & 14 & 28 & 56 & 90 & 14 & 28 & 56 & 90 \\
\hline 5 & 2.78 & 3.64 & 4.34 & 5.42 & 8.56 & 10.8 & 12.5 & 13.8 \\
\hline 10 & 1.57 & 2.16 & 3.51 & 4.58 & 7.5 & 8.1 & 9.3 & 10.7 \\
\hline 15 & 1.88 & 2.64 & 3.91 & 4.88 & 6.4 & 7.7 & 8.5 & 9.2 \\
\hline 20 & 1.54 & 1.67 & 2.27 & 3.55 & 5.1 & 6.58 & 7.65 & 8.45 \\
\hline 25 & 0.87 & 1.38 & 2.59 & 4.05 & 5.9 & 6.6 & 7.20 & 9.01 \\
\hline 30 & 0.43 & 2.54 & 3.51 & 4.32 & 6.3 & 7.5 & 8.62 & 9.25 \\
\hline
\end{tabular}

TABLE VI. SULPHATE ATTACK RESULT

\begin{tabular}{|c|c|c|c|c|}
\hline \multirow{2}{*}{ Mix proportion } & \multicolumn{4}{|c|}{ Reduction in weight \% } \\
\cline { 2 - 5 } & 14 & 28 & 56 & 90 \\
\hline 0 & 1.25 & 2.24 & 2.48 & 3.45 \\
\hline 5 & 1.20 & 2.34 & 2.75 & 2.98 \\
\hline 10 & 1.15 & 1.96 & 2.63 & 2.74 \\
\hline 15 & 1.10 & 1.90 & 2.48 & 2.56 \\
\hline 20 & 1.05 & 2.05 & 2.43 & 2.98 \\
\hline 25 & 1.01 & 2.53 & 2.71 & 3.15 \\
\hline 30 & 1.00 & 2.71 & 2.98 & 3.24 \\
\hline
\end{tabular}

TABLE VII. WATER ABSORPTION RATE TEST RESULT

\begin{tabular}{|c|c|c|c|c|}
\hline \multirow{2}{*}{ Mix proportion } & \multicolumn{5}{|c|}{ Average reduction in weight \% } \\
\cline { 2 - 5 } & 14 & 28 & 56 & 90 \\
\hline 0 & 3.34 & 3.53 & 3.45 & 3.28 \\
\hline 5 & 3.11 & 3.21 & 3.31 & 3.13 \\
\hline 10 & 3.00 & 2.87 & 2.72 & 2.64 \\
\hline 15 & 2.54 & 2.64 & 2.48 & 2.32 \\
\hline 20 & 2.61 & 2.75 & 2.55 & 2.46 \\
\hline 25 & 2.75 & 2,84 & 2.66 & 2.56 \\
\hline 30 & 2.55 & 2.32 & 2.24 & 2.18 \\
\hline
\end{tabular}

\section{CONCLUSION.}

1. High Strength SCC can be produced from the combination of Palm Oil Fuel Ash and conplast SP432MS superplastisizer being partially placed in cement. The optimum mix design was found to be 
1:2.5:2 together with $30 \%$ of POFA, water cement ratio of 0.35 and MS432 conplast superplastisizer.

2. The acid resistance test of SCC with palm ash had a high value compared with concrete mixes with ash at the ages of 28, 56 and 90 days.

3. When the specimen is immersed in sodium sulphate for 14, 28, 56 and 90 days, the average reduction in weight increased and the weight is decreased when the palm ash is increased in the concrete.

4. The water absorption percentage decreased with the increase in palm ash for $30 \%$ placement of ash, the low water absorption level is a good indicator of limited open porosity that can inhibit high flow of water into the concrete.

\section{REFERENCES}

[1] H. Okamura, "Self-compacting high performance concrete", Progress in Structural Engineering and Materials, Vol. 1, No. 4, pp. 378-383, 1998

[2] W. Zhu, J. Quinn, P. Bartos, "Transport properties and durability of self compacting concrete", 2nd International Symposium on SelfCompacting Concrete, Tokyo, Japan, pp. 451-458, 2001
[3] E. Mörtsell, E. Rodum, "Mechanical and durability aspects of SCC for road structures", 2nd International Symposium on Self-Compacting Concrete, Tokyo, Japan, pp. 459-468, 2001

[4] O. Makishima, H. Tanaka, Y. Itoh, K. Komada, F. Satoh, "Evaluation of mechanical properties and durability of super quality concrete”, 2nd International Symposium on Self-Compacting Concrete, Tokyo, Japan, pp. 475-482, 2001

[5] B. Persson, "Internal frost resistance and salt frost scaling of selfcompacting concrete”, Cement and Concrete Research, Vol. 33, No. 3, pp. 373-379, 2003

[6] J. John, T. M. Maya, T. Meenambal, "Mathematical modeling for durability characteristics of fly ash concrete”, International Journal of Engineering Science and Technology, Vol. 4, No. 1, pp. 353-361, 2012

[7] British Standards Institute, BS 12 Specification for Portland cement, BSI, 1996

[8] British Standards Institute, BS 1881 PT 108 Testing concrete. Method for making test cubes from fresh concrete, BSI, 1983

[9] British Standards Institute, BS 882 Specification for aggregates from natural sources for concrete, BSI, 1992

[10] ASTM, C494/C494M Standard Specification for Chemical Admixtures for Concrete, ASTM International, 2001 